\title{
Logistics Issues in the Brazilian Pig Industry: A Case-study of the Transport Micro-environment
}

\author{
Sivanilza Teixeira Machado ${ }^{1 \star}$, Irenilza de Alencar Naas ${ }^{1}$, João Gilberto \\ Mendes dos Reis ${ }^{1}$, Rodrigo Couto Santos ${ }^{2}$, Fabiana Ribeiro Caldara ${ }^{2}$, and \\ Rodrigo Garófallo Garcia ${ }^{2}$ \\ 1 Paulista University, Postgraduate Studies Program in Production Engineering, \\ Dr. Bacelar St. 1212, São Paulo, Brazil \\ 2 Federal University of Grande Dourados, Agricultural Sciences Department, \\ Rod. Dourados Itahum, km 12, Dourados, Brazil \\ sivateixeira@yahoo.com.br \\ http://www.unip.br
}

\begin{abstract}
Inadequate thermal characteristics inside a truck during livestock transport might lead to an important decrease meat quality and increase swine mortality. This study aims to assess the microenvironment characteristics of the pig transportation truck in tropical regions. These characteristics involve air temperature, relative humidity, wind and vehicle speed, and noise level. The present study compares two pig transportation schedules by assessing the ambient and pig surface temperature, and calculating the environmental temperature and humidity index (THI). The surface temperature was recorded using a thermal camera. Results showed that thermal characteristics inside the truck varied between the farm and the slaughterhouse plant $(p<0.0489)$. The unloading process at the slaughterhouse plant impacted the pigs surface temperature $(p<0.027)$ more than the loading management at the farm.
\end{abstract}

Keywords: Pig transport logistic, hot weather, pre-slaughter management.

\section{Introduction}

The key factor in a pre-slaughter logistics chain is the transportation system. The main links of the chain are the farm, transport and slaughterhouse plants. Transportation is essential throughout production. Typically, pigs are sent to the slaughterhouse plant by the farmer through some intermediaries not necessarily well trained in taking good care of the animals [1]. Maximizing the management between each supply chain component will help to minimized losses; therefore, reducing the weight loss in livestock transportation is an essential element in the meat supply chain. The pre-slaughter logistics scheme is presented in Figure 1.

\footnotetext{
* The authors wish to thank the CAPES.
} 


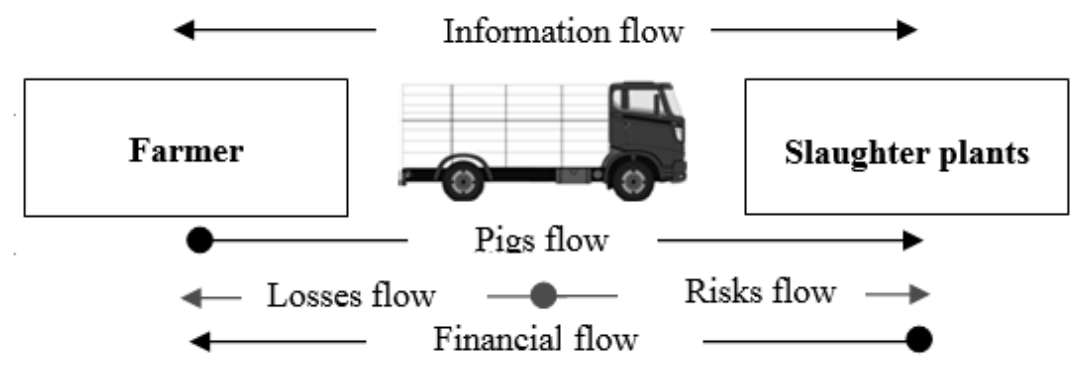

Fig. 1. Pre-slaughter logistics

High air temperatures and humidity impact negatively livestock production and animal welfare [2], [3]. The micro-climate inside the truck affects livestock production and animal welfare. Climate changing impact has led to global warming of approximately $1^{\circ} \mathrm{C}$ in the last 30 years affecting regional hydrological systems and agribusiness including livestock production [2], [4]. Brazil is the world fourth-largest pork producer and export [5] and the country is located in a tropical and sub-tropical region. The country swine herd is nearly 40 million heads, and approximately $80 \%$ of the production is concentrated in three main regions South, Southeast and Midwestern of Brazil [6]. High air temperatures and humidity impact negatively livestock production and animal welfare [2], [3]. Pre-slaughter logistics exceed the boundaries of the farm, and it involves mostly animal transportation [7], [8]. The thermal environment inside the truck lead to a loss in live weight, especially in large animals during long distances [9].

A major problem that farmers and slaughterhouse plants face is to determine the alignment between the slaughterhouse plant capacities with the pre-slaughter logistics, to comply with several issues, including animal welfare [7], [10]. Several slaughterhouse plants adopt the pigs transportation at night, due to the incidence of high temperatures during the day [11]. However, slaughterhouse plants production logistics usually imply in receiving the pig loads during the day, generally under the hot weather. At the slaughterhouse plant (final node of the chain), vehicles often have to queue while waiting to unload the pigs. Long queues at the slaughterhouses delivery point often cause problems for drivers and also negatively affect the animal welfare. Brazilian law required a total fasting time up to $24 \mathrm{~h} \mathrm{[12]} \mathrm{and} \mathrm{animals} \mathrm{under} \mathrm{fasting} \mathrm{time} \mathrm{after} \mathrm{above} 24 \mathrm{~h}$ must be fed. As this condition implies in the extra management of pre-slaughter logistics, it is avoided. Brazilian logistics performance adopts two different ways: (i) animals arrival at night are slaughtered in next morning; and (ii) animals arrival at morning are slaughtered in the afternoon.

Considering that while pigs are transported the truck microenvironment is a critical issue, this study aimed to assess the variation in the truck thermal conditions during two schedules in the afternoon. 


\section{Methodology}

The present study used hybrids finishing pigs from a commercial farm located in Espírito Santo State, Brazil $\left(6^{\circ} 20^{\prime} 4^{\prime} S, 35^{\circ} 18^{\prime} 33^{\prime} W\right)$. The experiment was conducted in February 2015. Pigs were transported in open truck with $7 \mathrm{~m}$ long and $2.45 \mathrm{~m}$ wide, wood body, two floors and two compartments per floor with a capacity of 70 animals (Table 1). The pigs transportation from farm to slaughterhouse plant had a distance of $45 \mathrm{~km}$. Two transportation schedules were monitored at 1 and 4 P.M.

Table 1. Characteristics of pigs transportation process from farm to slaughterhouse.

\begin{tabular}{ccccccc}
\hline $\begin{array}{c}\text { Period } \\
(\text { P.M. })\end{array}$ & $\begin{array}{c}\text { Weight of Pigs } \\
(\mathrm{kg})\end{array}$ & $\begin{array}{c}\text { 1st Floor } \\
\left(\mathrm{kg} / \mathrm{m}^{2}\right)\end{array}$ & $\begin{array}{c}\text { 2nd Floor } \\
\left(\mathrm{kg} / \mathrm{m}^{2}\right)\end{array}$ & $\begin{array}{c}\text { Loading } \\
(\mathrm{min})\end{array}$ & $\begin{array}{c}\text { Journey } \\
(\mathrm{min})\end{array}$ & $\begin{array}{c}\text { Unloading } \\
(\mathrm{min})\end{array}$ \\
\hline $1: 11$ at $2: 57$ & 123 & 260.0 & 246.0 & 24 & 75 & 7 \\
$3: 45$ at $5: 18$ & 120 & 254.1 & 240.0 & 18 & 60 & 15 \\
\hline
\end{tabular}

\subsection{Animals, pre-slaughter handling, and variables recorded}

A total of 140 finishing hybrid pigs (Landrace and Large White) had feed deprivation of six hours. During the loading process, the animals were moving in groups of six pigs. Pigs were moving from the pens to the truck on a hallway with a concrete floor until the wood dock that gave them access to the truck. The difference in the material of floor made the pigs stop in front of the dock. In this occasion, handlers used a kind of rattle to guide pigs inside the truck. The overall stocking density was $250 \mathrm{~kg} / \mathrm{m}^{2}$ [8], [10]. Pigs were sprinkled with water before the truck started moving to the processing plants. In the slaughter plant, pigs were unloaded, moving from the truck to the waiting pens. In these pens, the pigs remain a minimum of eight-hour in rest until the slaughter. During the fasting time, the transportation process and the rest the pigs had access only to water for $15 \mathrm{~h}$.

The variables ambient air temperature $(\mathrm{AT})$, relative humidity $(\mathrm{RH})$, wind speed (WS), truck speed (TS) and noise (N), and animals surface temperature (ST) were recorded. A data logger (Testo model 174H) recorded the variations in air temperature and humidity relative inside of truck during pigs transportation. The recording of wind speed and the noise was done using an anemometer (Krestel, Nielsen-Kellerman Co., US) and decibel meter (Testo model 815, Testo Co., Germany). The pigs surface temperature was assessed using a thermal infrared camera (Testo model 875, Testo Co., Germany). The measurements were taken every 5 min [13], during the logistics of the pre-slaughter phase, except the surface temperature that took place during the loading and unloading of animals. The thermal images were taken from the lateral of the truck in randomly select pigs located on the first and second truck floors. The measurement of AT 
and RH started with loading of the first animal and finished with unloading of the last animal [10]. The measurement of WS, TS and N were taken when the truck started moving from the farm to the slaughterhouse.

\subsection{Thermal environment, surface temperature analysis, and statistical method}

THI (Eq. 1) allows the assessment of pigs thermal comfort during transportation. The wet bulb temperature was calculated using $\mathrm{RH}$ as input in the software Psicrom [14].

The temperature humidity index (THI) was calculated as suggested by [15].

$$
T H I=0.45 W T+1.35 A T+32
$$

The average values of ST $\left({ }^{\circ} \mathrm{C}\right)$ were determined by selecting 40 points within the thermal image and using the software Testo Software IRSoft, Version 2.5 adopting the emissivity of the pig skin equal to 0.95 .

Data from the data logger were transferred to Excel and analyzed using Statistical Analysis System, version 9.0 [16] by Means and General Linear Models procedures. The THI values were calculated for the region climatic condition and inside studied sites (farm, truck, and slaughterhouse). Means of THI and ST of pigs were tested using T-test adopting a confidence value of $95 \%$.

\section{Results and Discussion}

No difference was found between the variables assessed during the pigs transportation process, except to $\mathrm{RH}(p=0.018)$. According to the recommended by $[17]$ the THI should be between $>57$ and $<62$. In the present study, the schedule of pigs transportation during the afternoon is unsuitable for the animals (Table 2).

Table 2. Average values of temperature (AT), relative humidity (RH), temperature and humidity index (THI), wind speed (WS), truck speed (TS) and noise (N) during pre-slaughter logistics.

\begin{tabular}{ccccccc}
\hline $\begin{array}{c}\text { Period } \\
\text { (P.M.) }\end{array}$ & $\begin{array}{c}\text { AT } \\
\left({ }^{\circ} \mathrm{C}\right)\end{array}$ & $\begin{array}{c}\text { RH } \\
(\%)\end{array}$ & THI & $\begin{array}{c}\text { WS } \\
(m / s)\end{array}$ & $\begin{array}{c}\text { TS } \\
(k / h)\end{array}$ & $\begin{array}{c}\text { N } \\
(\mathrm{dB})\end{array}$ \\
\hline $1: 11$ at $2: 57$ & 36.33 & $35.75^{b}$ & 91.76 & 0.94 & 47.0 & 81.13 \\
$3: 45$ at $5: 18$ & 36.03 & $41.05^{a}$ & 91.85 & 0.76 & 40.6 & 84.46 \\
\hline \multicolumn{7}{c}{$a b=$ Means with the same letter do not differ $(p>0.05)}$.
\end{tabular}

The truck micro-environment is determined by AT, RH and WS [13]. However, other variables also affect the truck microenvironment during transportation, such as stocking density, size, weight and age of animals, and vehicle motion. 
The monitoring procedure showed the variation in temperature and relative humidity during the transportation of pigs in three moments within two periods: loading, journey, and unloading (Fig. 2).
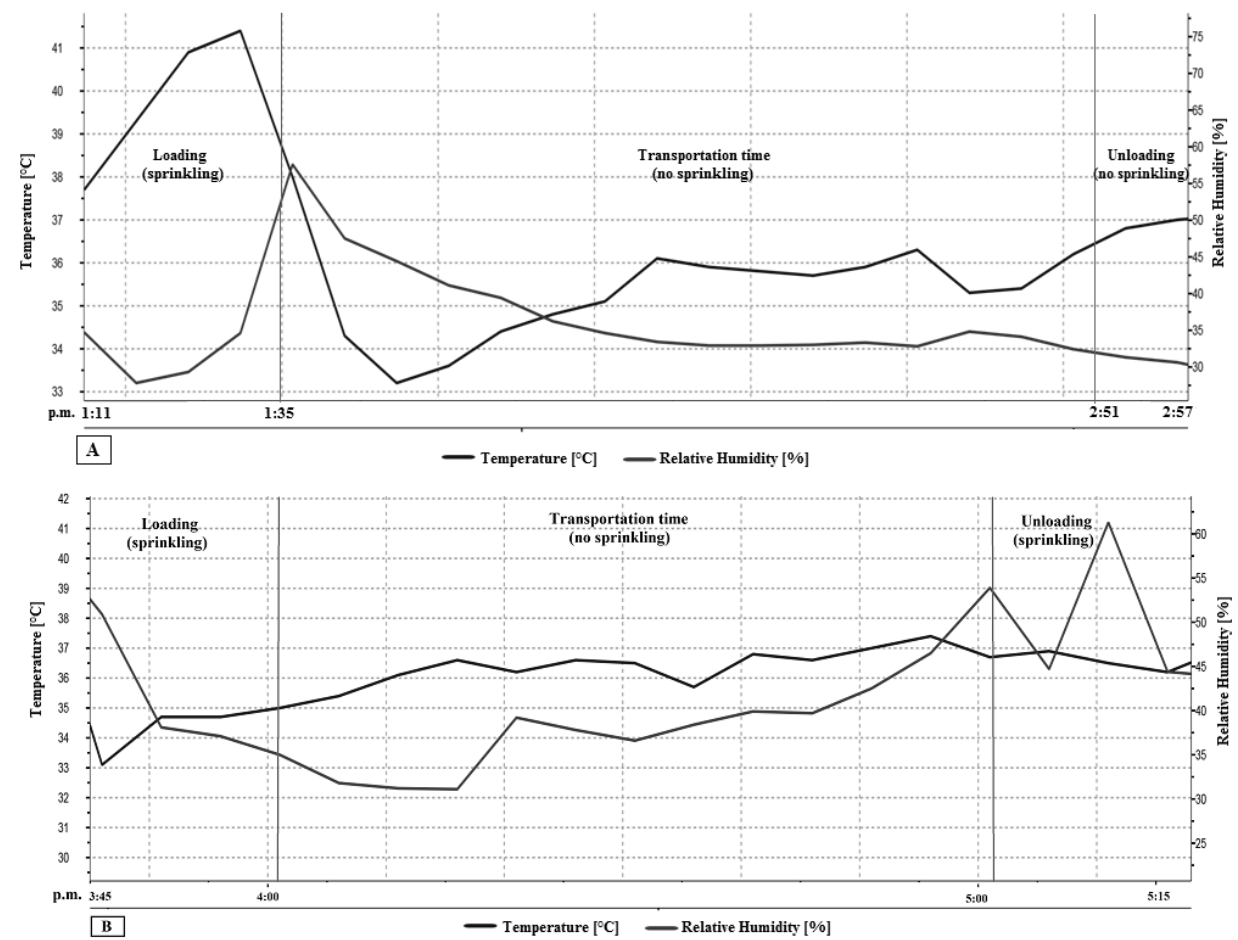

Fig. 2. Monitoring of air temperature $\left({ }^{\circ} \mathrm{C}\right)$ and relative humidity (\%) during pigs transportation from the farm to the slaughterhouse from 1:11 to 2:57 P.M. [A]; and from 3:45 to 5:18 P.M. [B].

Despite the variation be similar to both schedules of transportation, in the first transportation during the loading of animals, AT increased in $4.1^{\circ} \mathrm{C}$. With water sprinkling during loading AT values inside the truck decreased $8.2^{\circ} \mathrm{C}$. ST was not affected by sprinkling, but stress signs in pigs were observed [10]. In the present study, during the pigs transportation process AT increased gradually $2.5^{\circ} \mathrm{C}$. During the unloading process AT increase $1^{\circ} \mathrm{C}$.

Throughout the second schedule of transportation, AT increased $1.9^{\circ} \mathrm{C}$ during loading and $1.7^{\circ} \mathrm{C}$ during the journey. AT inside the truck decreased $0.7^{\circ} \mathrm{C}$ when water sprinkling of the animals was done before unloading at the slaughter plant. The thermal comfort varied 4.63 between farm and slaughter plant $(p<0.0489)$. The variation can be associated with the transportation process. No difference was found between the sites truck and slaughterhouse. However, 
truck and slaughter plant show different ambient THI values from the regional ones (Table 3). Such values indicate that both farm and meat processing industry should invest in environment control.

Table 3. Temperature Humidity Index (THI) values for the sites inside the farm, the truck and the slaughterhouse plant.

\begin{tabular}{lcccc}
\hline & Regional & Farm & Truck & Slaughterhouse \\
\hline THI $^{*}$ & $84.88^{b}$ & $86.75^{a b}$ & $90.92^{a}$ & $91.38^{a}$ \\
\hline$a b=$ Means with the same letter do not differ $(p>0.05)$.
\end{tabular}

AT and RH are variables responsible for the thermal comfort and welfare of livestock, and they may affect animals ST $(p<0.0001)$, Fig. 3 .

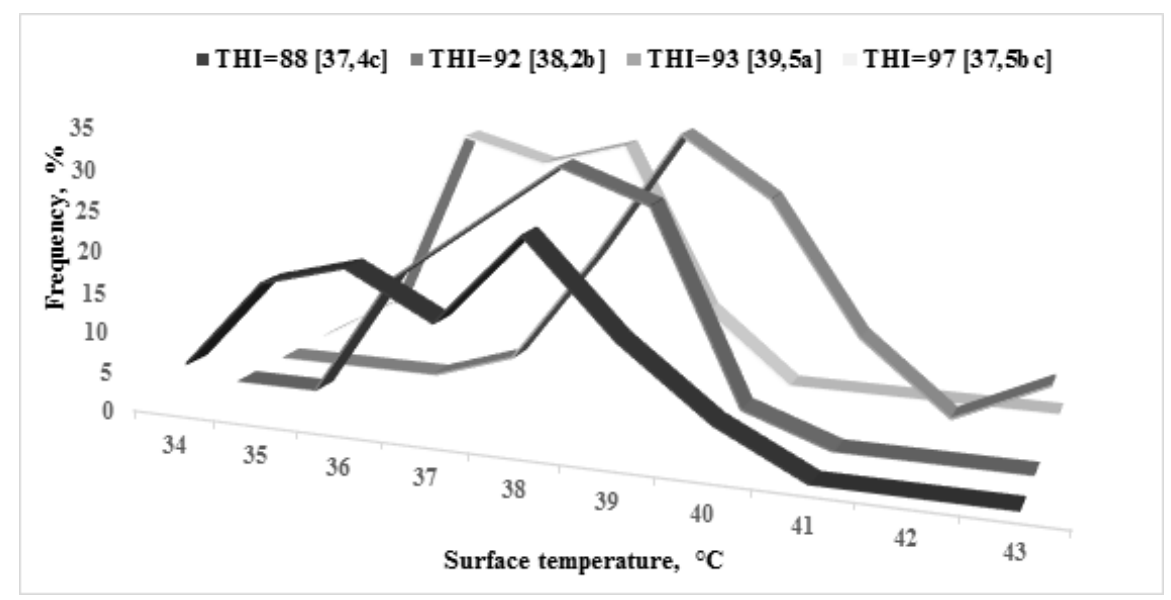

Fig. 3. Effects of Temperature Humidity Index (THI) at pre-slaughter logistics on the surface temperature (ST) of pigs in two-schedules of transportation.

Finishing pigs have difficulty to dissipate sensible heat, and it worsens when pigs are in heat stress due warm weather. Some action needs to be adopted by the pig supply chain to minimize this issue such as water sprinkling, adoption of forced ventilation, and improvement in the thermal material in the construction of the truck body. Pigs surface temperature increased $0.7^{\circ} \mathrm{C}$ in the first schedule of transportation and $1.7^{\circ} \mathrm{C}$ in the second schedule (Table 4 ). Results agree with the threshold of surface temperature observed by [10] in pigs transported during hot weather $\left(30.1-38.7^{\circ} \mathrm{C}\right)$.

Loading activities are preceding transportation process and the pigs ST has been affected by region and farm THI. Unloading activities $(p<0.027)$ occurred 
Table 4. Average values of the surface temperature (ST) of pigs during loading and unloading.

\begin{tabular}{ccccccc}
\hline Period (P.M.) & Number & Activity & Minimum Maximum Average & THI \\
\hline $1: 11$ at $2: 57$ & 34 & Loading & 35.1 & 39.6 & $37.5^{c}$ & $95.06^{a}$ \\
& 26 & Unloading & 36.5 & 40.0 & $38.2^{c}$ & \\
$3: 45$ at $5: 18$ & 36 & Loading & 34.4 & 40.1 & $37.4^{c}$ & $91.61^{b}$ \\
& 34 & Unloading & 37.0 & 43.0 & $39.1^{a}$ & \\
\hline \multicolumn{6}{c}{ Number = total of animals assessed per activity. } \\
$a b c=$ Means with the same letter do not differ $(p>0.05)$.
\end{tabular}

after transportation, and pigs ST were mostly influenced by the variables microenvironment inside the truck, time of transportation and region climate [9], [11]. Also, pigs transported on the second floor of the truck (mean $=40.1)$ showed a difference of $1.2^{\circ} \mathrm{C}$ when compare pigs located on the first floor (mean $=38.9$ ). [13] showed an increasing of dead pigs with increase the ST after transportation.

\section{Conclusions}

Transport of livestock requires special care, becoming a challenge logistic issue along the chain. In developing countries, the available transport infrastructure is relatively poor with inappropriate maintenance. Inadequate logistics services are associated not only with product loss but also with the spread of disease at different stages of food supply chain. Although logistics risk in livestock production covers a wider scope, this study focused on the element transportation from the node farm to the node slaughterhouse plant, with the focus on the truck microenvironment.

Adequate environmental control might reduce the effect of the temperature humidity index on pigs surface temperature, leading to increase the animal thermal comfort and welfare. The present study concludes that pigs farmers and pork industry should invest in the pre-slaughter logistics. Adopting the transport the livestock during the morning or at night is needed, as those operations during the afternoon might provide an inappropriate thermal comfort.

\section{References}

1. Miranda-de la Lama, G.C.M.d.l., Villarroel, M., Mara, G.A.: Livestock transport from the perspective of the pre-slaughter logistic chain: a review. Meat Science 98(1), $9-20$ (2014)

2. Naas, I.d.A., Romanini, C.E.B., Salgado, D.D., Lima, K.A.O., Vale, M.M.d., Labigalini, M.R., Souza, S.R.L.d., Menezes, A.G., Moura, D.J.d.: Impact of global warming on beef cattle production cost in Brazil. Scientia Agricola 67(1), 01-08 (2010) 
3. Silva, B.A.N., Noblet, J., Donzele, J.L., Oliveira, R.F.M., Primot, Y., Gourdine, J.L., Renaudeau, D.: Effects of dietary protein level and amino acid supplementation on performance of mixed-parity lactating sows in a tropical humid climate. Journal of Animal Science 87(12), 4003-4012 (2009)

4. Intergovernmental Panel on Climate Change: Climate change 2014: synthesis report. Tech. rep., Intergovernmental Panel on Climate Change, Geneva, (2014), http://www.ipcc.ch/

5. Foreign Agricultural Service: Livestock and poultry: world markets and trade. Tech. rep., United States Department of Agriculture (2014)

6. Instituto Brasileiro de Geografia e Estatística: Produção da pecuária municipal (2011), http://www.ibge.gov.br

7. Oliveira, L.M.F.d., Yanagi Junior, T., Ferreira, E., Carvalho, L.G.d., Silva, M.P.d.: Bioclimatic mapping of southern Brazilian region for animal and human thermal comfort. Engenharia Agrcola 26(3), 823-831 (2006)

8. Amaral, A.L., Silveira, P.R.S., Lima, G.J.M.M., Klein, C.S., Paiva, D.P., Martins, F.: Boas práticas de produção de suínos. Tech. rep., Empresa Brasileira de Pesquisa Agropecuária (2006), http://www.cnpsa.embrapa.br

9. Silva, I.J.O., Vieira, F.M.C.: Ambiência animal e as perdas produtivas no manejo pré-abate: o caso da avicultura e corte brasileira. Archivos de Zootecnia 59, 113-131 (2010)

10. Kephart, R., Johnson, A., Sapkota, A., Stalder, K., McGlone, J.: Establishing sprinkling requirements on trailers transporting market weight pigs in warm and hot weather. Animals 4(2), 164-183 (2014)

11. Bench, C., Schaefer, A.L., Rushen, J.P., Passill, A.M., Faucitano, L., Lewis, N., Gonyou, H., Bergeron, R., Widowski, T.: Welfare implication of pig transport journey duration: scientific background of current international standards. Tech. rep., Agriculture and Agri-Food Canada (2008)

12. BRASIL: Regulamento da inspeção industrial e sanitária de produtos de origem Animal (1952), http://www.agricultura.gov.br

13. McGlone, J., Johnson, A., Sapkota, A., Kephart, R.: Temperature and relative humidity inside trailers during finishing pig loading and transport in cold and mild weather. Animals 4(4), 583-598 (2014)

14. Roriz, M.: Psicrom 1.0 software Relações Psicométricas (2003)

15. W. L. Roller and R. F. Goldman: Response of swine to acute heat exposure. Transactions of the ASAE 12(2), 0164-0169 (1969)

16. Statistical Analysis System: SAS/STAT 13.2 Users Guide (2014)

17. Leal, P.M., Naas, I.A.: Ambiência animal. Unicamp, Campinas, SP, 1 edn. (1992) 